\title{
Basel Accords on Risk Management: A Survey of Kenya's Commercial Banks
}

\section{Ojwang George Omondi}

Department of Business Studies, Siaya Institute of Technology, Kenya

*Corresponding author: Ojwang George Omondi, Lecturer, Department of Business Studies, Siaya Institute of Technology, Kenya, Tel: +0203586198; E-mail: georgeojwang@gmail.com

Rec date: Aug 24, 2015; Acc date: Dec 1, 2015; Pub date: Dec 7, 2015

Copyright: @ 2015 Omondi OG. This is an open-access article distributed under the terms of the Creative Commons Attribution License, which permits unrestricted use, distribution, and reproduction in any medium, provided the original author and source are credited.

\begin{abstract}
In 2012 the Central bank of Kenya issued revised and new prudential and risk management guidelines applicable to commercial banks, mortgage finance companies and non-bank financial institutions licensed under the Banking Act of Kenya. This was informed by the need to up-date the banking sector regulatory framework in light of significant changes in local, regional and global banking sector's operating environment. Key drivers included a desire to adapt new global best practices in banking sector such as the revised Basel Core Principles Banking Supervision. Among the guidelines issued include regular stress testing by commercial banks and the submission of a report to Banking Supervision Department on a quarterly basis. This paper investigated risk management techniques employed by commercial banks in Kenya and recorded several techniques including stress testing and contingency planning.
\end{abstract}

Keywords: Back testing; Sensitivity analysis; Stress testing; Trend analysis; Value at risk

\section{Introduction}

\section{Background of the study}

Traditionally, banking supervision has been vested in a country's central bank under the authority of the finance minister. Under this arrangement, too-big-to-fail policy has favored poor banking supervision as taxpayers have been called upon to bail out failing banks through the exchequer. The executive as well as politicians including the finance minister consider banks as sources of disposable funds rather than a source of risks that could drastically derail proper functioning of financial markets unless the exchequer comes in with a rescue package.

Supervision of the banking sector by the central bank in most cases is skewed against taxpayers' welfare as governments and banks strike an unwritten accord for mutual existence. Banks' investment priorities are thus compromised by politicians' wishes because solvency of these banks remains solely with the government. Governments are rarely concerned with risks facing banks to an extent that all-round supervision is subservient to political goals.

Large commercial banks in Kenya by asset category including; Kenya commercial bank limited and Equity bank limited have extended their operations across the border to Tanzania, Uganda, Rwanda and Southern Sudan. This has been necessitated by dwindling profit margins at home from intense competition waged for clients among the salaried group. At the same time, micro-finance institutions have recently become deposit taking institutions thus offering commercial banking services to capture the once unbanked section of society. Due to intensive coverage of telecommunication network in Kenya, mobile money transfer services like M-PESA, ZAP, M-KESHO, ORANGE MONEY, YU-CASH and M-SHWARI have transformed commercial banking in Kenya to an extent that commercial banking is no longer a brick and mortar set up.

Charles Goodhart's saying that banks are international in life, but national in death, should resonate deeply with Kenya's commercial banks. The sovereign debt situation in Europe is as much a banking crisis as it is a financial crisis. The cost of bail out to France' Credit Agricole and German Commerzbank will not only be borne by national taxpayers but by taxpayers all over the world. It therefore calls upon external forces to come into play in regulating commercial banks' portfolio composition even as domestic central banks implement set guidelines. The American experience shows that if banking supervision and monetary policy are managed by the same authority, monetary policy will be subservient to banking supervision. This is a most unwelcome scenario.

The complexity of financial institutions may make it difficult to discern linkages within the financial system at large.

\section{Market risk}

Market risk is the risk that the value of an investment will decrease due to moves in market factors. Volatility frequently refers to the standard deviation of the change in value of a financial instrument with a specific time horizon.

\section{Operational risk}

Operational risk is the risk that is not inherent in financial, systematic or market-wide risk. It is the risk remaining after determining financing and systematic risk, and includes risks resulting from breakdowns in internal procedures, people and systems.

\section{Credit risk}

A credit risk is the risk of default on a debt that may arise from a borrower failing to make required payments. In the first resort, the risk 
is that of the lender and includes lost principal and interest, disruption to cash flows, and increased collection costs.

\section{Basel committee}

The Basel Committee on Bank Supervision is a committee of the world's bank regulators that meet regularly in Basel, Switzerland. In 1988 it published what has become known as The Bank for International Settlement Accord or simply The Accord. This Accord primarily determines the calculation of capital to be held by a commercial bank to contain credit risk as a result of its loan book. Several years later, the Basel Committee published The 1996 Amendment implemented in 1998 requiring commercial banks to incorporate market risk as well as credit risk in the calculation of buffer capital. This Amendment separates a bank's trading book from its banking book. The trading section comprises; stocks, bonds, and derivative instruments like swaps and options most of which are revalued on a daily basis.

The Banking book on the other hand comprises loans; personal, industrial or otherwise and are mostly long term in nature thus not revalued frequently. This amendment calculates buffer capital for the trading book using the VaR measure with $\mathrm{N}=10$ and $\mathrm{X}=99$. It focuses on revaluation over a 10 day period that is expected to be exceeded only $1 \%$ of the time. A Value at Risk (VaR) calculation aims at making a statement of the form: "we are $\mathrm{X} \%$ certain that we will not lose more than $\mathrm{V}$ dollars in the next $\mathrm{N}$ days.

\section{Bank for international settlements}

The feudal system worked in the 1920s as it works today through the medium of private central banks in each country that control national money supply of individual economies. In the 1920s and 1930s the New York Federal Reserve System, the Bank of England, the Reichsbank in Germany and Banque de France influenced the political apparatus of their respective countries indirectly through control of money supply and creation of monetary environment.

In the 1930s the guiding vehicle for this international system of financial and political control called by Carol Quigley the "Apex of the System" was the Bank for International Settlements in Basle, Switzerland. She states, the process of financial capitalism had another far reaching aim, nothing less than to create a world system of financial control in private hands able to dominate the political system of each country and the economy of the world as a whole. Indeed, Sutton, concurs that the BIS apex continued its work during world war two as the medium through which the bankers continued a mutually beneficial exchange of ideas, information and planning for the post war world.

Ten times a year except in August and October, a small group of individuals arrives in Basel in Switzerland for the regular meeting of the most exclusive, secretive and powerful supranational club in the world. The membership of this club is restricted to a handful of powerful individuals who determine daily the interest rate, availability of credit and money supply of the banks in their own countries. The place where this club meets in Basel is a unique financial institution called the Bank for International Settlements (BIS) originally established in May 1930 by bankers and diplomats of Europe and the United States to collect and disburse Germany's world war one reparation payments.
Although the BIS was organized as a commercial bank with publicly held shares, its immunity from government interference and taxes in both peace and war was guaranteed by an international treaty signed in the Hague in 1930. In practice this bank is not a commercial bank by its operations for individuals cannot operate account maintenance with bank. Since it provided, in Basel, a safe and convenient repository for gold holdings of European central banks, it quickly evolved into the central banks' bank. As the world depression deepened in the 1930s and financial panics flared up in Austria, Hungary, Yugoslavia and Germany, governors in charge of key central banks feared that the global financial system would collapse unless they could closely coordinate their rescue efforts.

The obvious meeting spot for this desperately needed co-ordination was the BIS, where they regularly went away to arrange gold swaps and war damage settlements. But the BIS is not a monolithic institution: artfully concealed within the shell of an international bank, like a series of Chinese boxes one inside another, are the real groups and services the central bankers need. These groups are guided by the belief that central banks should act independently of their home governments for politicians should not be trusted to decide the fate of the international monetary system. There also exists a strong preference for pragmatism and flexibility over any ideology whether it is Maynard Keynes or Milton Friedman for when the bell tolls for any single central bank it tolls for them all.

The first box inside this artful organization is the board of directors drawn from European central banks; England, Switzerland, Germany, Italy, France, Belgium, Sweden and the Netherlands. It meets on the Tuesday morning of each "Basel weekend" to define the rules and territories of the central banks with the goal of preventing governments from meddling in their purview. The second box is the Group of Ten called G-10 though it has 11 fulltime members representing the US Fed, Bank of Canada, Bank of Japan, England, Switzerland, Germany, Italy, France, Belgium, Sweden and the Netherlands.

It also has one unofficial member: the governor of the Saudi Arabian Monetary Authority. It is this group that controls most of the transferable money in the world and meets on Monday afternoon of the "Basel weekend" to discuss policy issues like interest rates, money supply growth, economic stimulation or suppression and currency rates. A small unit called the Monetary and economic development department is directly under the G-10 and acts as a think tank. Its head sits on all G-10 meetings and assigns appropriate research and analysis to its staff. In fact, Epstein, indicates that it is this unit that produces occasional blue bound "economic papers" called the Basel accords [1].

The Basel Accords are some of the most influential and misunderstood agreements in modern international finance. Drafted in 1988 and 2004, Basel 1 and 2 ushered in a new era of international banking co-operation. Through quantitative and technical benchmarks, both accords have harmonized banking supervision, regulation and capital adequacy standards across the world. On the other hand, the very strength of both accords limit the understanding of these agreements within policy circles; causing them to be misinterpreted and misused in many of the world's political economies.

\section{Basel 1}

Base 1 only proposes Minimum capital requirements for internationally active banks and invites banks alike to be more conservative in their banking regulations. Moreover, it warns that 
capital adequacy ratios cannot be viewed in isolation and as the ultimate arbiters of a bank's solvency. It comprises 4 pillars

Pillar 1 Constituents of capital: It defines types of on-hand capital counted as reserves and quantity to be held. This Accord categorizes capital reserves into two tiers. Tier 1 capital consists of disclosed cash reserves and paid up equity. Tier 2 includes capital created to cover potential bad loans, holding of subordinated debt, hybrid debt/ equity instrument holdings and potential gains from sale of assets financed through bank stock. Both tiers must be held proportionately.

Pillar 2 Risk weighting: It creates a comprehensive system to risk weight a bank's assets and loan book. Five risk categories encompass all assets in a bank's balance sheet. First category, Riskless assets at $0 \%$ risk, includes cash in bank vault, sovereign debt held and funded in domestic currency. Second category weights assets at 20\% low risk assets including multilateral development bank, bank debt with a maturity of less than one year, cash items in collection and loans guaranteed by public sector entities.

The third category, Moderate risk, includes residential mortgages weighted at 50\%. Fourth category, High risk, weighted at $100 \%$ includes bank claims on the private sector, bank debt with a maturity of more than one year, Eurobonds and equity assets. Fifth category, Variable, includes claims on domestic public sector entities which can be valued at $0,10,20$, or $50 \%$ depending on a central bank's discretion.

Pillar 3 a target standards ratio: It unites first and second pillars by setting a universal standard whereby $8 \%$ of a bank's risk weighted assets must be covered by tier 1 and tier 2 capital reserves. Moreover, tier 1 capital must cover $40 \%$ of a bank's risk weighted assets. This ratio is seen as minimally adequate to protect against credit risk in deposit insurance-backed international banks in all Basel Committee member states.

Pillar 4 transitional and implementing agreements: It sets forth implementation of the Basel Accords. Each country's central bank is required to set up a strong surveillance and enforcement mechanism to ensure transition weights are given so that banks can adapt over a 4 year period to the set standards. Basel 1 is not without its shortfalls which culminated in drafting of Basel 2.

Basel 1: Initially was intended for regulating banking operations within the G-10 countries and its subsequent spillover to check banking operations in emerging economies was non-intended. At the same time, Basel 1 only concentrated on managing credit risk at the expense of stressing overall financial market discipline by players in the financial sector.

The pomp and flare with which implementation of Basel 1 was launched was more of a marketing strategy than a technical one. It was intended to be the blue print for financial prudence by commercial banks despite its unforeseen financial loopholes. It was the in thing to do by any international bank to subscribe to the tenets of Basel 1. This was concentrating risk management in a barrel approach sealing all hopes of external strategies lying outside the Basel 1 schedule of risk weighting.

Basel 2: The shortcomings aforementioned with reference to Basel 1 led to a proposal in 1999 for a second accord, more comprehensive in capital adequacy known formally as A Revised Framework on International Convergence of Capital Measurement and Capital Standards. This is the Basel 2 accord which is an expanded agreement encompassing new approaches to credit risk, adapts to securitization of bank assets, targets operational and interest rate risks including market based surveillance and regulation. To present its guidelines, Basel 2 uses pillars approach just like Basel 1.

Pillar 1: Minimum capital requirement: Assets of holding companies are monitored to avoid transferring the same to subsidiaries thereby avoiding weighting of the same in computation of Value at Risk (VaR). This is a buildup on Basel 1 which omitted such regulatory oversight on financial engineering. This pillar analyzes banking risk in three different categories; the standardized approach extends Basel 1 capital weights to include market based rating agencies like Standard and Poor, Moody's and Fitch. Corporate debt and bank debt are weighted the same way except for debts rated $\mathrm{BBB}+$ and $\mathrm{BB}-$ which are rated at $100 \%$. Other debts rated below BB- are weighted at $150 \%$ whereas unrated debt receives $100 \%$ weighting. Mortgages are in their own class with corporate mortgages receiving $100 \%$ weighting while home mortgages are weighted at $35 \%$.

Basel 2 proposes internal capital weighting using the Foundation/ Internal Ratings Based Approach which allows banks to develop, with the approval of regulatory authorities, probability of default models for in-house weighting of their loan books. It is incumbent on regulatory authorities to provide probability of loss for each type of asset, bank exposure at default time and maturity risk of each asset type. Advanced internal ratings based approach is most suitable to large banks capable of implementing use of complex models to determine the assumption of proprietary default

Pillar 2: It concentrates on regulator-bank interaction by extending regulatory power to oversee bank's internal risk evaluation, review bank capital assessment policy and even hold the se banks' directing minds responsible for information misrepresentation. Regulators have widened powers to establish additional capital requirements above the minimum capital for crisis management purposes and as a protective measure against public bailout of too large to fail commercial banks. At the same time this pillar allows regulators to step in as soon as it is detected that a bank's capital base has fallen below the minimum required level by implementing corrective measures to counter this stressful scenario.

Pillar 3: To improve on market discipline, this pillar recommends public disclosure of both capital and risk taking positions of banks through their financial statements. Contingent liabilities should be broken down into consumable pieces of information discernible even to the investing public not gifted in finance literature analysis. This is intended to improve on monitoring activities aimed at curtailing moral hazards by bank shareholders thereby avoiding public bailout of too big to fail commercial banks.

\section{Banking sector in Kenya}

The Kenya banking sector has been experiencing challenging times due to global integration of the financial system. On the external front, a hostile economic environment and poor macro-economic policies have held performance at low levels. Internally, poor supervision by the Central Bank of Kenya, a slow and cumbersome judicial process, poor debt culture and political patronage conspired against the well being of the banking sector. According to Banking Survey, general low profitability of the industry is due to high volume of non-performing loans (NPLs). In 2003, the industry reported NPLs of Ksh 73 billion representing $27 \%$ of total advances. Banks have incurred heavy loses as a result of massive provisions and write-off on loan books.

Apart from the usual financial reports, all registered banks in Kenya have to publish unaudited quarterly disclosure statements including a 
Page 4 of 9

range of financial and prudential information. A key component of these statements has been the disclosure of a bank's capital adequacy ratio. Whenever a registered bank falls below minimum capital requirement, it must present a plan of capital restoration to at least the minimum required level. In early 1990s, commercial banks in Kenya took advantage of astronomical rise in treasury bills and bond rates by allocating a large portion of their portfolio to this riskless asset class for handsome capital gains and excessive profits.

Interest rates were only stabilized by the Central Bank of Kenya Act known as the Donde act of 2000. The uncertainty of the Donde Act caused several commercial banks to seek alternative ways of revenue generation. Mwiraria, in his budget speech of 2004, invoked section 44 of the Banking Act, compelling commercial banks to seek permission from the finance minister prior to raising bank charges.

Similarly, Iregi concedes that banks have therefore been compelled to generate revenue through consumer loans to a small market of salaried group resulting in poor loan appraisal and intense competition by different commercial banks.

\section{Statement of the problem}

According to the Banking Supervision Annual Report 2013, the Kenya banking sector comprises 43 commercial banks, one mortgage finance company, 7 representative offices of foreign banks, 9 microfinance banks, 2 credit reference bureaus, 1 money remittance provider and 101 foreign exchange bureaus.

The amendment of the Banking act through the Finance Act 2010 ushered in the penetration of banking services detached from the brick and motor branch network. This was achieved through conduct of banking operations through third party agency popularly called Agency banking. Such a proliferation of banking services to the remote parts of the country comes at a cost in terms of risks which have to be effectively measured and managed. Historical simulation on Kenya commercial banking operation is littered with bank failures due to poor risk management.

In 1993, six financial institutions were placed under liquidation. One of these institutions, Inter-Africa credit Finance which was placed under liquidation on 31st January, 1993 had only Ksh 4 million worth of deposits as insured deposits. This is dismal in comparison to Trade bank placed under liquidation on 18th August, 1993 with insured deposits of Ksh 280 million. Deposit protection is a risk management measure taken by all commercial banks with The Deposit Protection Fund, a department within the Central Bank of Kenya. Between 1993 and 2005, 20 financial institutions were placed under liquidation.

Even though credit risk is a major cause of banking instability, market risk seems to weigh heavily on the risk management function by commercial banks in Kenya. The move by Kimunya as the finance minister to raise minimum capital levels for commercial banks to Ksh 1 billion was as a buffer against bank runs. Well capitalized financial institutions stand a better chance of containing liquidity problems which would otherwise result in bank runs and panic across the financial market. The 3 Basel accords so far released are standards upon which banking stability is enhanced globally. Their implementation commencement dates differ by country basis. This research hereby seeks to analyze risk management and measurement techniques employed by commercial banks in Kenya with a view to meeting Basel 2 requirements as its major objective. To achieve this objective, the research is guided by the question;

\section{Importance of the study}

Finance Literature: This research sheds light on the importance of commercial banks as key players in the financial markets infrastructure and their interlinkages. It aims to be a secondary source for further research in financial economics and investment management.

Investment Stakeholders: This paper seeks to awaken curiosity about commercial banking operations and their implications on riskreturns trade-off. This is in direct response to Euro land debt crisis with respect to risky investments to the Greek nation by the French bank, Credit Agricole and the German bank, Commerzbank.

Behavioral Finance: The study adds to the growing importance of emotional stability and heuristics as a component of investment management unlike traditional finance that concentrates on numerics at the expense of psychosocial drivers.

Regulatory purposes: The research adds to a growing pool of measures and checks to be implemented by regulators like the capital markets authority and Central bank of Kenya in the financial markets infrastructure to ensure smooth operations and boost investor confidence.

The remainder of the article is organized as follows; the next section explores literature relevant to the topic under review followed by a discussion of research methodology. A discussion of the results is available under the section on data analysis. The final section concludes and presents directions for further research.

\section{Literature review}

Severe economic crises are usually associated with banking sector distress. Being highly leveraged financial participants, bank capital can be wiped out quickly when asset quality and value deteriorate during a crisis. In this regard, Chan concedes that a devastated banking sector endangers a country's payment system, the provision of liquidity and the extension of credit all of which can lead to a broader economic recession. Similarly, Kotlikoff indicates that the only legitimate purpose for the existence of banks and related institutions is financial intermediation. Systemic instability sets in when financial institutions deviate from this core mandate and instead focus on peripheral activities.

In Kenya distressed commercial banks have been put under receivership by the Deposit Protection Fund Board (DPFB), a department of the Central Bank of Kenya, for failing to meet minimum standards of operations. Daima bank, Trust bank, Fortune Finance, Trade bank and Euro bank have been victims of non-compliance and thus transferred their liabilities to DPFB.

Risks from the banking system can spread to sovereigns as governments increase their debts to rescue the economy and systematically important banks which are too big to fail. Therefore it is imperative for policy makers to improve resilience of the banking sector. McNeil et al. summarizes the scope of credit risk: "credit risk is the risk that the value of a portfolio changes due to unexpected changes in the credit quality of issuers or trading partners. This subsumes both losses due to defaults and losses caused by changes in credit quality", (page 327). In this regard, credit risk is central to a commercial bank's financial stability and its mismanagement could make the entity a gone concern. 
A commercial bank's portfolio comprises loans as a major portion which contributes to positive returns thus encouraging upside risk. Down side risk as a component of loans arises when a commercial bank fails to subject its loan portfolio to algorithmic models. Loan categories like liar loans, non-documentation loans, NINJA (no income, no job and no asset) loans should be professionally evaluated to ensure that the financial superhighway operates smoothly. Failure to professionally curb adverse selection during loan approval stage drastically compromises returns on such asset classes. The magnitude of such a loss determines the health of the entity's capital.

Coyle indicates that credit risk is a loss emanating from refusal or incapacitation of debtors to pay off what they owe in full when time demands of them to do so. Commercial banks as financial intermediaries play a critical role by matching maturities of their assets to liabilities. They delicately balance short term customer deposits against long term loans. When these loans mature up and the loanees are not in a position to honour their part of the deal then commercial banks are left holding worthless pieces of paper to match depositors' unpredictable requests.

Such risks arise from limited institutional capacity like poor technology and low quality of workforce leading to poor loan underwriting. At times, government interference in the form of directed lending to financially vulnerable sectors of the economy or to politically correct projects which are junk by investment standards could also derail a commercial bank's matching of maturities. Commercial banks are subject to regulation from the Central Bank of Kenya. Due to political affiliation or biased composition of the Board of Directors, some institutions have been left off the hook of central bank of Kenya thereby destabilizing smooth operation of the financial market.

This was the case in 2011 when interest rates rose substantially and the value of the Kenya shilling dropped drastically against international currencies. Maturity mismatches between a commercial banks' assets and liabilities is the greatest factor threatening financial stability of these crucial financial intermediaries. In fact Kashyap, Acharya, [2,3] concur that maturity mismatches arise from banks funding of risky assets with short term borrowing from depositors fund base [2].

A look at the risk taking behavior of commercial banks management reveals that their remuneration is pegged on performance with aggressive risk taking attracting hefty pay packages. This scenario creates a moral hazard between these managers and the shareholders in terms of agency problem. The managers would like to take on more risk with a likelihood of better pay package.

The situation is made worse by a lack of a strong internal control mechanism in the form of a staff risk management function. Similarly Shleifer, [4] talks about inconsistency within bank management to give risk management the executive recognition it deserves. Risk functions are rarely accorded the executive powers they deserve with the head of risk lagging in remunerations compared to the chief executive officer. A cross sectional analysis of banks reveals that some commercial banks withstand financial crisis better than others due to the autonomy of their risk management function (Senior Supervisors Group, 2008) despite being guided by the same risk management guidelines.

Similarly Acharya, [5] concedes that the inability of some commercial banks to adequately monitor their trading desks resulting in huge financial losses through rogue traders makes a mockery of regulatory authorities' supervision and external market discipline expected of shareholders and bond holders. It is therefore imperative that a commercial bank puts in place a strong risk management function with executive powers. Hence Acharya and Stulz, [5,6] suggest having a strong internal system which correctly identifies and measures risk exposure of various banking operations both on-balance sheet as well as off-balance sheet. Indeed, Senior Supervisors Group contend that during the financial crisis banks with a strong autonomous risk management function with clear channels of communication between management and banking staff sustained their profitability [7]. It boils down to an all-inclusive affair from the board members down to the most junior staff of the commercial bank.

Due to their intermediary function within the financial market, commercial banks find themselves in the business of risk taking. In this regard, Purnanandam, assert that some commercial banks having realized this sorry state embrace it with pragmatism by opting for risky investments but supported by a strong risk management function with enhanced hedging techniques [8]. In fact, Beltratti and Stulz, examining bank performance relative to board autonomy conclude that banks with shareholder friendly boards performed worse during the financial crisis of 2008 unlike those banks in countries with strict capital requirement regulations with autonomous supervisors who performed better by comparison [9]. However, Minton et al. suggest that financial expertise of directors is directly associated with risk taking whereby directors with high financial literacy are prone to excess risk taking resulting in higher firm value prior to financial crises [10].

Similarly, Erkens et al. observe that CEO turnover is more sensitive to shareholder losses among financial institutions with greater board autonomy, larger institutional ownership and smaller insider ownership. Institutional investors carefully monitor their investment prospects which inform their asset mix and would not hesitate to revise such a mix to maintain positive returns. Board autonomy plays a role for it gives the board the leeway to act professionally and be fully responsible for investment returns [11]. This also applies to a smaller insider ownership whereby emotional attachment to the trading activities of an organization becomes a gray area. The Kenyan situation is different because most commercial banks are integrated in terms of board membership and shareholding with the economic power directly linked to political power. Bank CEOs rarely quit their positions but vertically move to other corporates in total disregard of past performance. Share ownership is concentrated in the ruling elites and struggling middle class.

Mitigation of these drawbacks calls for stable interest rate regime from an independently functional central bank led by a non-partisan governor, well capitalized commercial banks as was proposed by Kimunya (former minister of finance in Kenya) and institutionalization of credit sharing information in the legal system. In Kenya, two credit reference bureaus are operational with Credit Reference Bureau (CRB) Africa limited licensed in 2010 being the first entity to perform this highly important facet of loan generation. Then in April 2011, Metropol limited was granted an operational license. Such measures reduce chances of adverse selection during loan generation by commercial banks.

Credit risk management requires a comprehensive approach for its success. There is need to establish clear institutional structures without grey areas with adequate delegation of tasks to independent offices well poised to bear responsibility for actions taken in the line of duty. In this regard, Lindgren suggests that, risk management calls for disciplined processes with clear channels of communication. What is at times 
lacking in Kenya's banking system is failure to segregate duties and unclear reporting lines. Every bank officer should be given a lee way to make decisions provided they are in lie with the organization's overall strategic plan. The company's mission, vision, core values and motto should be inscribed in each employee so that they are guided by these principles in their daily operations.

Demirguc et al. observe that there are two phases to bank credit management. First we have the Newtonian reaction against bank loses with the realization that there is inadequate buffer capital to absorb them. Credit risk measurement helps in curbing this through improved monitoring and evaluation of moral hazards. Secondly, innovations like commercial paper and loan securitization have opened new avenues for commercial banks to grow their loan portfolios exponentially. Loan securitization in Kenya would improve the quality of loan books by improving the capital base of these banks. Banks would therefore generate to distribute loans without recourse to their capital base by sacrificing personal touch with their clients.

Similarly, Sounders suggests that banks need adequate information on potential customers to be able to calibrate their credit risk profile. In this regard, Simson and Hempel, Kane and Rice, concur that credit risk profile could be captured from international credit rating agencies like Moody's investor service or from credit reference bureaus like Metropol limited in Kenya. Hence, Griffith and Persuad suggest that it is imperative for commercial banks to avoid subjectivity in loan underwriting by use of approved quantitative models of lending.

The assessment and evaluation of credit exposure by each prospective loan application is guided by a bank's credit policy. Flannery and Rangan, Polizatto, Popiel, assert that sound credit policy improves asset quality by establishing minimum set of standards to apply and the methodology of implementation. Measurement and reporting of non-performing assets, loan categorization and provisions for bad and doubtful debts form part of a sound credit policy.

In the financial marketplace, the trend towards some sort of global governance is best represented by the efforts of bank supervisors under the aegis of the bank for international settlements in Basel to impose common minimum capital requirements on banks and to integrate and co-ordinate the supervision of banking, securities markets and insurance.

The Basel Committee on Banking Supervision has been issuing guidelines to minimize credit risk exposure and enable commercial banks better respond to such a risk with minimal effects on the financial markets globally. Basel 1 aims at harmonizing different approaches to capital ratios among the G-10 country commercial banks.

Basel 2, recognizing the importance of shareholders' equity as a component of capital, consists of three pillars: Pillar 1 stresses enhanced buffer capital of commercial banks to cover all business risks outside credit, market and operational risks. Pillar 2 concentrates on Supervisory role by requiring them to assess internal capital adequacy processes that banking institutions have put in place. Pillar 3 captures market discipline; commercial banks are required to disclose their management parameters in terms of identification, measurement and mitigation.

New regulatory mandates under Basel 3 Banking rules will also challenge banks as compliance costs add to the equation. Approved in September 2010 by the Basel Committee on Banking Supervision of the Bank for International Settlements, the new standards and requirements will be phased in 2019 and are aimed at improving the resilience and safety of the global banking system. Quintanilla, 2012 concurs that among other requirements including new processes and reporting, banks will have to increase their capital reserve amounts. A November 2010 report from McKinsey and company states that, Basel 3 is more than just another set of checks and balances for financial institutions in a post crisis world. It represents the core component of a sweeping wave of regulation that will fundamentally affect the profit generation capacity of banking industry. The proposed Basel 3 guideline seeks to improve the ability of banks to withstand periods of economic and financial distress by prescribing more stringent capital and liquidity standards.

Capital buffers have been introduced and loss absorptive capacity of Tier 1 and Tier 2 capital instruments of internationally active banks is to be enhanced. Forward looking provisioning has been prescribed and modification made in counterparty credit risk weights. New parameters of leverage ratio and liquidity standards prescribed for all commercial banks. These guidelines seek to enhance minimum core capital, introduce capital concentration buffer to be built up in times of excessive credit growth at the national level. The Committee suggests that a new buffer of $2.5 \%$ of risk weighted assets covering minimum core capital requirement of $4.5 \%$ to be created by commercial banks.

A consultative document issued in August 2010 proposes the introduction of a "write off clause" in all Tier 1 and Tier 2 instruments issued by internationally active banks. Main features include capital instruments to be written off on occurrence of trigger events and instrument holders to be compensated immediately in the form of common stock. Any injection of funds or support without which the bank in distress would become non-viable is to be made public.

The proposed contingent capital clause is intended to ensure that holders of capital bear the loss in a stress scenario before public money is infused and that they do not benefit from this infusion. The clause is intended to reduce the possibility of support for a commercial bank under stress as the bank's core capital base would get strengthened at the expense of non-core capital holders

\section{Research Methodology}

\section{Research philosophy}

Any research undertaking must be aligned to the subject of concern which can be education, psychology or business. Generally, the philosophical orientation of any research should be established within which a detailed research approach is developed. Positivism as a philosophy asserts that all knowledge must be empirical and verifiable, dismissing anything based on opinion, speculation or conjecture. This philosophy does not fit well with business research where unstructured interviews generate rich tacit data from a broad range of respondents' opinions. Business research seeks solutions from human participants and is not tied specifically to statistical analysis. Phenomenology on the other hand supports determination of a research approach, strategy and design as it offers insights and interpretation of complex problems rather than just statistical analysis of quantifiable information. According to Stanford Encyclopedia of Philosophy phenomenology is the study of conscious experience as experienced from the subjective or first person point of view. Interpretivism as a philosophy on its part suggests that knowledge is a product of interpreting the environment and what people think about it. It is therefore subjective in approach and closely linked to phenomenological philosophy. 


\section{Research approach}

Phenomenology and Interpretivism are closely aligned to two research approaches of deduction and induction. Whereas it can be said that deduction is a top-down approach which validates a developed theory through testing and confirmation, induction is down-to-top approach as it builds a theory based on collected and analyzed data. Deductive approach emphasizes scientific principles by moving from theory to quantitative data collection in order to explain causal relationships between variables in a highly structured approach without researcher interference with appropriate samples chosen to fit overall generalization. Inductive approach emphasizes an understanding of the meanings humans attach to events within a research context through collection of qualitative data in a more flexible manner in the realization that the researcher is part of the research process. As this research seeks to study risk management techniques of commercial banks in Kenya, a middle ground synchronizing these two approaches was adopted.

\section{Research purpose}

Saunders et al. purport that research is undertaken for different purposes; explanatory, exploratory, descriptive or a combination of all these three. Whereas an exploratory study collects data to develop a theory, a descriptive study leads to a comprehensive record of a situation without necessarily drawing conclusions. An explanatory study seeks the understanding and establishment of relationships between variables in a causal manner. This research attempts to gain an understanding of operations of commercial banks in Kenya and their risk implications and consequent mitigation techniques which calls for the study to be both explanatory as well as exploratory.

\section{Research strategy (Design)}

The research design adopted was consistent with an explanatory and exploratory research purpose taking cognizance of the synchronization between deductive and inductive approaches. In this regard, Sounders et al. contend that an experimental design involves acquisition of primary data through observation for the approval of a hypothesis. Researcher participation through introduction of variables into the research environment and the assessment of consequential impact is very necessary. This design was ruled out because the researcher is currently an academic and is not engaged productively with any commercial bank other than for account maintenance purposes and cannot therefore fully participate in the daily operations of commercial banks. An archival design focuses on records and circumstances but this was also ruled out for need of contemporary data. A survey approach allows for collection of quantitative data consistent with a deductive approach and exploratory purpose. This fits well with the current research when complimented with case study design. A case study provides contemporary data through qualitative unstructured interviews in which participants bring forth their tacit knowledge on the topic under research. A combination of these two designs provided a rich data set for this research focusing on how well the commercial banks understand risks inherent in their operations, how well prepared are these banks in handling various risks be they systematic and/or unsystematic and how effective their risk mitigation techniques are.

\section{Data collection}

Quantitative data was captured through questionnaires administered to 10 respondent commercial banks in Kisumu county through drop and pick later format. This ensured that data could be captured from these ten participants at their convenience but within a set period of time efficiently. Non-response to questions was accorded a follow up within a fortnight but in most cases a mean response was applied. These questionnaires were complimented by unstructured interviews aimed at capturing tacit information from the respondents which is qualitative in nature. These two methods of data collection were intended for triangulation purposes.

\section{Ethics}

The researcher considered the sensitivity of data captured in terms of public disclosure of strategic intentions of participant commercial banks which could be utilized for comparative advantage in this competitive business environment. Good corporate governance calls for clear channels of communication with personnel bearing full responsibility for their actions and utterances and the task of public relations is a staff task bestowed upon a department and no intention whatsoever was envisaged by the researcher prior to collection of data for personal financial rewards or otherwise from data collected. This remains purely a research process for improvement of risk management purposes within the financial markets. All participants volunteered the data captured and were in no way coerced or induced either by promises of financial rewards or threats to their normal business undertakings. Confidentiality of participants was clearly stated by the researcher prior to participation by respondents

\section{Data Analysis}

\section{Introduction}

This research was carried out through a descriptive survey method with the guiding research question being, which risk management techniques (Table 1) are applicable by commercial banks in Kenya in compliance with Basel Accord on Banking Supervision? Revised Basel 2 focuses on managing market risk. Different techniques were being used by different banks with an $80 \%$ of the banks surveyed using more than 4 different techniques concurrently.

\begin{tabular}{|l|l|}
\hline Technique & Percent of respondents \\
\hline Stress testing & 100 \\
\hline Back testing & 40 \\
\hline Contingency planning & 80 \\
\hline Value at risk & 75 \\
\hline Trend analysis & 60 \\
\hline Scenario planning & 30 \\
\hline Internal rating programs & 50 \\
\hline
\end{tabular}

Table 1: Risk management techniques are applicable by commercial banks in Kenya. 
Page 8 of 9

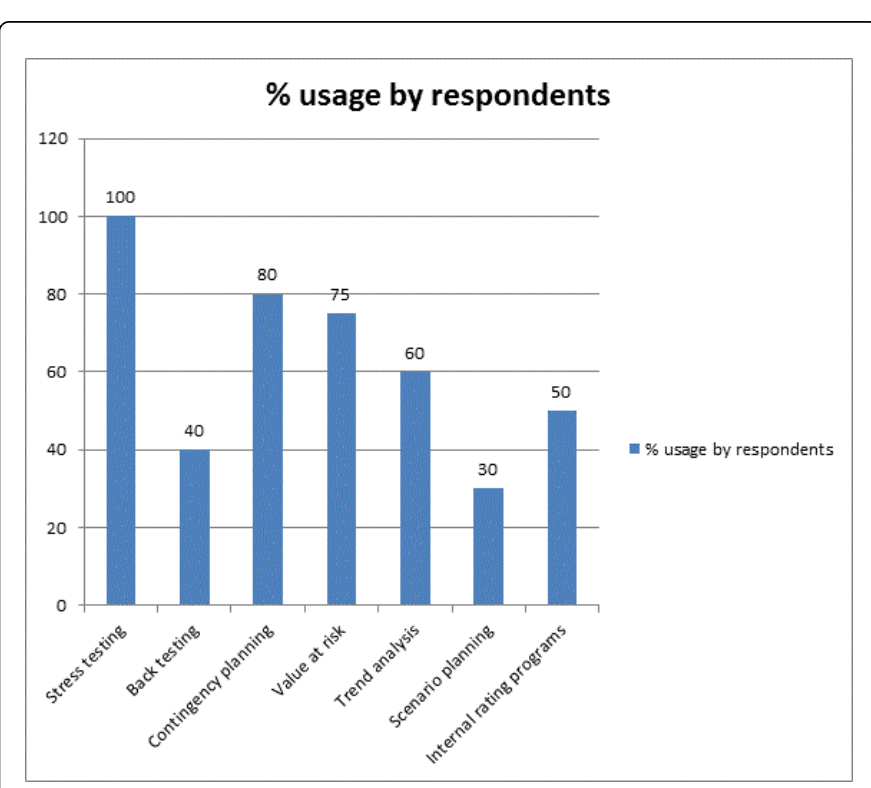

Figure 1: Represents risk management techniques employed by commercial banks in Kenya and their popularity of usage by the respondent banks. Data sourced from field survey.

\section{Discussion}

Section 6 D of part 2 of the Basel 2 Framework outlines the internal models approach to risk management. The use of this approach by Kenya's commercial banks is conducted on approval by the Central bank of Kenya, the supervisory authority. It requires the board of directors and senior management to be actively involved in the risk control process and must regard risk control as an essential aspect of the business to which significant resources need to be devoted. In $70 \%$ of the cases the board of directors were involved in the whole process receiving monthly risk reports whereas $90 \%$ of respondents had senior management being involved with weekly risk reports being analyzed by heads of departments. The banks internal risk measurement model must be closely integrated into the day to day risk management process of the bank. From Figure 1 Stress testing is employed by all the respondent banks and the results of stress testing are used as a supplement to the risk analysis based on the day to day output of the banks' risk measurement models. Basel 2 revised version states that banks' stress tests should be both quantitative and qualitative incorporating both market risk and liquidity aspect of market disturbances. Quantitative criteria should identify plausible stress scenarios to which banks could be exposed. Qualitative criteria should emphasize the identification of steps that the bank can take to reduce its risks and conserve capital and to evaluate the bank's capacity to absorb potential large losses.

$70 \%$ of respondent banks had a routine in place for ensuring compliance with a documented set of internal policies, controls and procedures concerning the operation of the risk management system. This routine check is carried out by the internal audit department in $80 \%$ of the cases while the board of directors is involved in $20 \%$ of the cases and executive risk management committee is responsible in $10 \%$ of the cases.

\section{Conclusion}

Commercial banking is prone to risks from both its banking books and trading books. This is an undertaking founded on how firms involved manage the risk component of their operations. The twin factors of adverse selection and moral hazards are daily occurrences to commercial banks. This emanates from loan advances offered to borrowers without adequate consideration to lending policies and subsequent failure to monitor those loans. The portfolio of most commercial banks is highly geared with loans being the largest asset class.

Risk management and measurement is therefore crucial in the existence of not only any other business enterprise but more so to a financial institution like a commercial bank. Failure to manage risk is equivalent to failing the shareholders of the banks under study and their boards as well as senior management would be call to account for these mishaps. This research therefore propagates earlier research by expanding the role of boards and senior management in terms of risk management for the survival of commercial banks.

From the research several risk management techniques are employed by commercial banks in Kenya including Stress testing, Back testing, Contingency planning, calculation of Value at Risk, Trend analysis, Scenario planning and Sensitivity analysis and Internal ratings programs. It is further revealed that most commercial banks utilize more than four techniques concurrently to manage and measure risk particularly market risk, operational risk and credit risk.

The study was however not without its shortcomings, the sample size of 10 commercial banks in Kisumu county might not be representative enough of the operations of the 44 commercial banks in Kenya. A more central location like Nairobi county would have been representative enough of the vibrant commercial aspect of the banking industry in Kenya. Even though the respondents in the survey were representative of management not all their answers could be without errors. The researcher treated all the responses as true reflection on the status of affairs of individual commercial banks but behind this assumption could be found adulterated data for strategic purposes. In as much the Basel 2 Accord requires high quality human capital, the employment situation within the Kenyan economy is without its shortfall. Aspects of board members interference abound in every aspect of the banks operations. Right from the appointment of the governor of the Central bank of Kenya to outsourcing of cleaning services by commercial banks, future research could be undertaken to determine the risk components of bank holding groups like Standard chartered bank relative to their commercial bank counterparts like Trans-National bank.

\section{References}

1. Epstein EJ (1997) Ruling the world of Money. Monetary Reform Magazine.

2. Kashyap AK, Rajan RG, Stein JC (2008) Rethinking capital regulation.

3. Acharya VJN, Carpenter X, Gabaix K, John M, Richardson MG, et al. (2009) Measuring systemic risk.

4. Shleifer A (2011) The Transformation of Finance. Lecture at American Finance Association.

5. Acharya VVT, Philippon M, Richardson N, Roubini (2009) The Financial crisis of 2007-2009: Causes and remedies. Financial Markets, Institutions \& Instruments 18: 89-137.

6. Stulz RM (2008) Risk management failures: What are they and when do they happen? Social Science Research Network. 
Citation: Omondi OG (2015) Basel Accords on Risk Management: A Survey of Kenya's Commercial Banks. J Glob Econ 3: 164. doi: 10.4172/2375-4389-1000164

Page 9 of 9

7. Senior Supervisors Group (2008) Observation on risk management practices during recent market turbulence.

8. Purnanandam A (2007) Interest rate derivatives at commercial banks: An empirical investigation. Journal of Monetary Economics 54: 1769-1808.

9. Beltratti A, Stulz R (2009) Why did some banks perform better during the debt crisis? A cross country study of the impact of governance and regulation.
10. Minton B, Taillard JP, Williamson R (2010) Do independence and financial expertise of the board matter for risk taking and performance?

11. Erkers D, Hung M, Matos P (2009) Corporate governance in the recent financial crisis: Evidence from financial institutions worldwide. 